\section{Microbiological quality of drinking water in Amarja reservoir catchment, Aland taluk, Karnataka, India}

\author{
Syed Shams Rizvi* and M. A. Mohammed-Aslam \\ Department of Geology, Central University of Karnataka, \\ Kalaburagi 585367, India
}

Geogenic and anthropogenic activities are the main reasons for the deterioration of groundwater quality. Different kinds of microbial pathogens present in drinking water are responsible for gastrointestinal and waterborne diarrhoeal diseases. The present study estimates the microbial quality of drinking water of Amarja reservoir catchment in Aland taluk, Karnataka, India. Thirty-two water samples were taken from different villages in the study area. Microbiological parameters like Escherichia coli and coliform bacteria, Pseudomonas aeruginosa, sulphite-reducing anaerobes and aerobic plate count at $37^{\circ} \mathrm{C}$ was analysed. The results showed that 18 of the 32 samples were positive for $E$. coli and total coliform, 17 samples for $P$. aeruginosa and 18 samples for sulphite-reducing anaerobes. Moreover, six samples were positive for both $E$. coli and sulphite-reducing anaerobes, whereas five samples were positive for sulphite-reducing anaerobes and $P$. aeruginosa.

Keywords: Aerobic plate count, drinking water contamination, Escherichia coli, Pseudomonas aeruginosa, sulphite-reducing anaerobes.

NowADAYS, it has become a challenge to provide safe drinking water ${ }^{1}$. Contamination of groundwater resources is mainly responsible for the deterioration of its quality ${ }^{2,3}$. Microbiological pathogens are the most dangerous pollutants in drinking water ${ }^{4,5}$. Most of the waterborne diseases are directly related to microbiological contamination that is largely based on the need to identify the indicators of pollution ${ }^{4-7}$. Therefore, microbiological analysis has become an important step for detecting microbial pollutants in drinking water. Separating the pathogens growing in the intestinal tract of humans and animals in the laboratory is a challenging task. Viruses, bacteria and protozoa are the major causes of harmful diseases. The influence of diarrhoeal disease in human beings can be minimized with good sanitation, fairish dumping of human beings' and other vertebrates' dropping ${ }^{1}$. Enterobacteriaceae is the most common family of microorganisms that contaminates drinking water; it includes common species like Escherichia coli ${ }^{1}$.

The analysis of physical parameters of water includes determination of $\mathrm{pH}$, total dissolved solids (TDS), elec-

*For correspondence. (e-mail: shamsrizviamu@gmail.com) trical conductivity (EC) and turbidity. The $\mathrm{pH}$ value represents the hardness of water. Turbidity represents the limpidity of water in terms of individual particles, organic matter, plankton, etc. TDS is a measure of total ions in solution. The ratio between the current density and electric field intensity is known as electrical conductivity.

Coliform bacteria are generally Gram-negative with a rod-shaped structure ${ }^{5}$. They belong to the genera Klebsiella, Enterobacter, Citrobacter and Escherichia ${ }^{2}$. According to modern taxonomical methods, this group is heterogeneous in nature ${ }^{1}$. These bacteria have been categorized as total coliform, faecal coliform and E. coli. Bacteria which belong to the total coliform family generally exist in soil or vegetation. The source of total coliform bacteria could be faecal or environmental befoul. Faecal coliform is a subgroup of the total coliform group of bacteria that exist in the intestines and faeces of humans and animals ${ }^{6}$. E. coli is a subgroup of faecal coliform bacteria. The existence of these bacteria in drinking water are very harmful. They grow in a timespan of $12-$ $72 \mathrm{~h}$ with temperature variation between $30^{\circ} \mathrm{C}$ and $37^{\circ} \mathrm{C}$ under favourable conditions.

$P$. aeruginosa is also a Gram-negative bacterium, which can be distinguished by its Gram-morphology with the capability to grow at $42^{\circ} \mathrm{C}$. Fluorescence under ultraviolet light is helpful in early identification of $P$. aeruginosa colonies. The incubation period of Pseudomonas bacteria is noticed from 24 to $72 \mathrm{~h}$. The nature of $P$. aeruginosa infection can be identified by isolation and laboratory investigation of pathogens. The treatment of infections due to $P$. aeruginosa has become difficult, as it resists the common antibiotics. However, the intermixture of gentamicin and carbenicillin sometimes reduces $\mathrm{Pseu}$ domonas infections.

Sulphite-reducing anaerobes are Gram-positive and free-living bacteria. They may be found in the intestinal tract of humans, decaying vegetation, marine sediments and also in a few other vertebrates. They can live in the water for a longer time ${ }^{8}$. Sulphite-reducing anaerobes can reduce down sulphite to sulphide at $37^{\circ} \mathrm{C}$ within $24 \mathrm{~h}$. The most common species of sulphite-reducing anaerobes is Clostridium perfringens that includes several significant pathogens.

Aerobic plate count (APC) is a method used to determine the level of the microorganisms (bacterial populations) in drinking water. APC serve as a good indicator in the efficacy of different processes responsible for the treatment of drinking water like disinfection, coagulation and filtration ${ }^{1}$. APC are used in the measurement of level of sanitary quality and organoleptic properties. The acceptable limit of aerobic colony count is $20 \mathrm{cfu} / \mathrm{ml}$ at $37^{\circ} \mathrm{C}$. The microorganisms occur in drinking water as single-cell structures, pair colonies, group structures, chain structures and dense bunches. Each individual freeliving bacterium does not grow in a different colony on incubation. Therefore, the number of colonies which 


\section{RESEARCH COMMUNICATIONS}

Table 1. Norms for microbiological parameters according to BIS (IS-14543)

\begin{tabular}{lll}
\hline Parameters & \multicolumn{1}{c}{ BIS code } & \multicolumn{1}{c}{ ISI unit } \\
\hline Escherichia coli & IS 5887-1976 (Part 1) & Absent \\
Coliform bacteria & IS 5401-2002 (Part 1) & Absent \\
Sulphite-reducing anaerobes & Annex C of IS-13428 & Absent \\
Pseudomonas aeruginosa & Annex D of IS-13428 & Absent \\
Aerobic microbial count & IS 5402-2002 & $20 \mathrm{cfu} / \mathrm{ml}$ at $37^{\circ} \mathrm{C}$ in $24 \mathrm{~h}$ \\
Turbidity (NTU) & IS-3025 (Part 10) & $<2 \mathrm{units}$ \\
pH & IS-3025 (Part 11) & $6.5-8.5$ \\
Total dissolved solids (TDS) & IS 3025 (Part 16) & $<500 \mathrm{mg} / \mathrm{L}$ \\
\hline
\end{tabular}

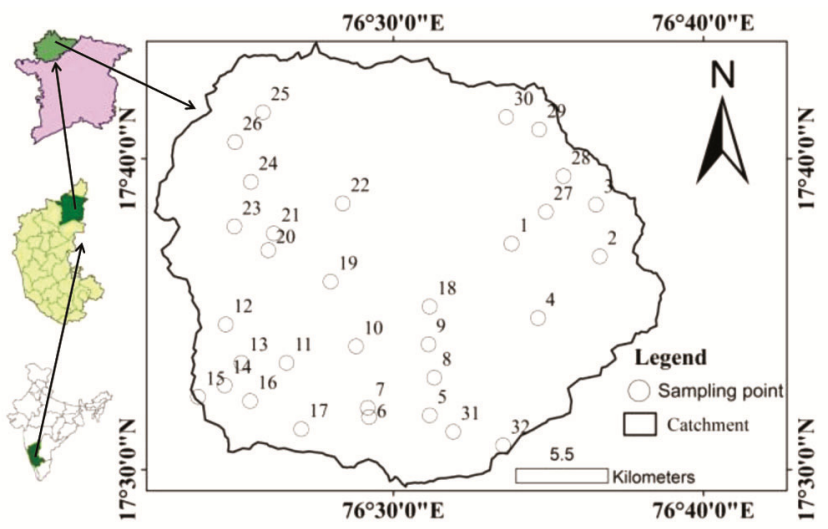

Figure 1. Sampling location of Amarja Reservoir Catchment.

occur on the plate does not indicates the total number of bacteria in the test volume of a sample ${ }^{1}$.

The Amarja reservoir catchment covering an area of $544.76 \mathrm{sq} . \mathrm{km}$ in Aland taluk, Karnataka lies between $17^{\circ} 50^{\prime} 9^{\prime \prime}-17^{\circ} 72^{\prime} 20^{\prime \prime} \mathrm{N}$ lat and $76^{\circ} 45^{\prime} 8^{\prime \prime}-76^{\circ} 55^{\prime} 20^{\prime \prime} \mathrm{E}$ long (Figure 1). The area falls under semiarid region of the Deccan plateau (basalts). The rocks are composed of soft and hard lava flows whose weathering has produced flattopped hills and terrace-like features. Ridges, pediments, flat and undulating landscape are the main structures in the area. The highest contour of $600 \mathrm{~m}$ elevation is at the northern part, while the lowest contour of $475 \mathrm{~m}$ is at the southern part of the catchment. The area contains deep black soils generally derived from Deccan traps. The summer season is from February and June. The southwest monsoon is from June to September. December is the coldest month having a temperature variation from $29.5^{\circ} \mathrm{C}$ to $10^{\circ} \mathrm{C}$. In the peak of summer, temperature can rise up to $45^{\circ} \mathrm{C}$. The relative humidity is about $26 \%$ in summer and increases up to $62 \%$ in winter. The area receives an average annual rainfall of about $777 \mathrm{~mm}$ while the annual minimum rainfall is $342 \mathrm{~mm}$ and the annual maximum rainfall is $1270 \mathrm{~mm}$ (ref. 9).

A total of 32 samples were collected from different locations in the study area. These samples were further analysed according to the norms suggested by BIS-14543 (Table 1) for the different microbiological and physical parameters.
For sample collection, narrow-mouth, high-density, stainless steel bottles of 1 litre capacity were utilized. The bottles were sterilized using an autoclave. Sterile rubber gloves and face mask were used while collecting the samples. The sampling point (tap, pipe, etc.) was sprayed 4-5 times with $70 \%$ alcohol and after 2 min the water samples were collected in the sterile bottles ${ }^{10,11}$.

$E$. coli and total coliform bacteria were detected using MacConkey broth, eosin methylene blue (EMB) agar and violet-red bile (VRB) agar. P. aeruginosa was detected using asparagine proline broth and cetrimide agar. Moreover, sulphite-reducing anaerobes test was done using differential reinforced clostridial broth (DCRB), and aerobic microbial count test was done to check the microbial load and hygiene status of the water samples.

For the detection of coliform bacteria and E. coli, $250 \mathrm{ml}$ of water sample was filtered through $0.2 \mu \mathrm{m}$ membrane filter, inoculated and transferred into $30 \mathrm{ml}$ MacConkey broth. The broth was prepared using $30 \mathrm{ml}$ screw-cap bottles in which a Durham tube was kept in an inverted position. After inoculation, the bottles were incubated at $37^{\circ} \mathrm{C}$ for $48 \mathrm{~h}$. Positive results were indicated by a colour change of the broth and presence of air bubble in the Durham tube. The positive samples were further inoculated onto EMB agar plates for E. coli and simultaneously onto VRB agar plates for coliform bacteria. The plates were kept under incubation at $37^{\circ} \mathrm{C}$ for $48 \mathrm{~h}$ (ref. 6). E. coli strain showed green metallic sheen on EMB agar, whereas coliform bacteria showed green metallic sheen on VRB broth.

For the identification of $P$. aeruginosa, $250 \mathrm{ml}$ of water sample was filtered through the $0.45 \mu \mathrm{m}$ membrane and transferred into asparagine-proline broth tubes. The tubes were incubated at $37^{\circ} \mathrm{C}$ for $48 \mathrm{~h}$. The growth and fluorescence were examined under UV light. The presence of $P$. aeruginosa was recorded by a subculture of a loopful of culture medium on Cetrimide Agar plate that was kept for incubation at $37^{\circ} \pm 0.5^{\circ} \mathrm{C}$ for $48 \mathrm{~h}$. The presence of $P$. aeruginosa was marked by pigmentation and fluorescence under UV light.

Differential reinforced clostridial medium (DRCM) was used to detect the sulphite-reducing bacteria. The water sample has been heated in a water bath at $75^{\circ} \pm 5^{\circ} \mathrm{C}$ for $15 \mathrm{~min}$. Then $50 \mathrm{ml}$ of double-strength 
DRCM medium was prepared in two separate $100 \mathrm{ml}$ screw-cap bottles that were sterilized. Next $50 \mathrm{ml}$ of water sample was added into one bottle with medium and the other bottle was kept as control. Further, singlestrength DRCM medium was added up to the neck of the bottles ensuring that some air remains inside then the bottles were sealed and incubated at $37^{\circ} \mathrm{C}$ for $48 \mathrm{~h}$. The confirmation of sulphite-reducing anaerobes was done by observing blackening as a result of the reduction of sulphite and precipitation of iron sulphide.

Plate count agar (PCA) medium was used in this study. The water sample was mixed thoroughly and then $1 \mathrm{ml}$ of the sample was transferred into sterile petri dishes. The sterilized PCA media was transferred aseptically into the same petri dishes and was kept for solidification. While transferring the media to petri dishes, the temperature was set around $40^{\circ} \mathrm{C}$ to $45^{\circ} \mathrm{C}$. After solidification of the media, the petri dishes were incubated at $37^{\circ} \mathrm{C}$ for $24 \mathrm{~h}$. Results were analysed on the basis of colony count and reported as Total Plate Count of $\mathrm{cfu} / \mathrm{ml}$ of the water sample.

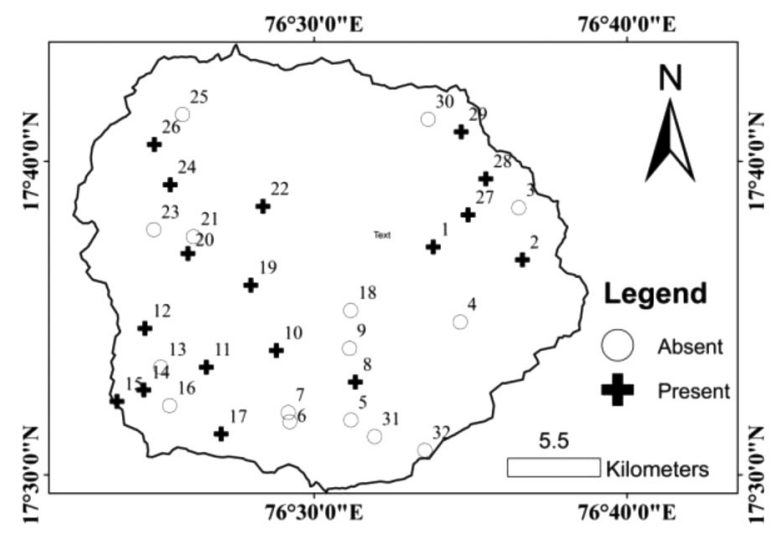

Figure 2. Total caliform and Escherichia coli in Amarja Reservoir Catchment.

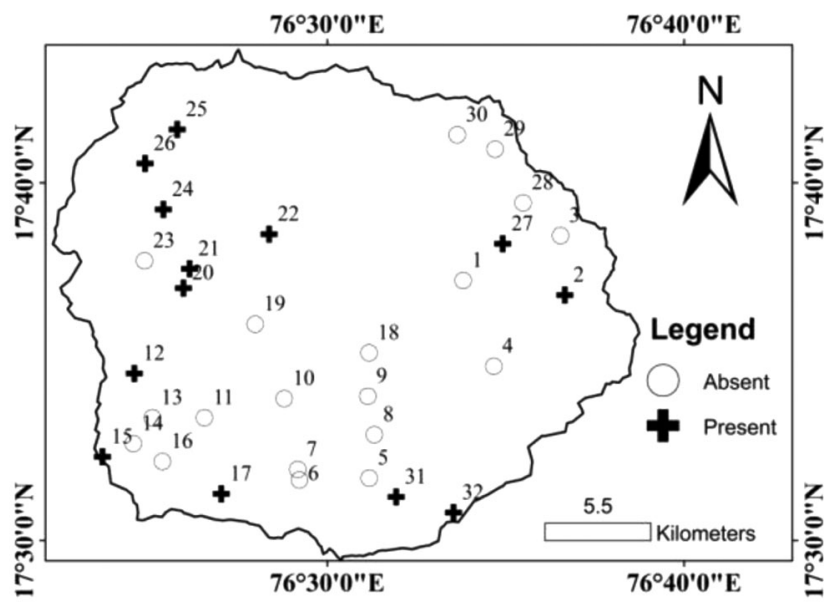

Figure 3. Pseudomonas aeruginosa in Amarja Reservoir Catchment.
Total coliform and E. coli, $P$. aeruginosa and sulphitereducing anaerobes were recorded as absent or present. The northwest (NW) and southwest (SW) parts of the study area were more affected by coliform bacteria and E. coli while the south-southeast (S-SE) part was less affected (Figure 2). In the case of $P$. aeruginosa the NW part was more affected, while the east and S-SE parts were less affected (Figure 3). Furthermore, sulphite-reducing anaerobes affected the NE, SW and southern parts of the catchment (Figure 4). APC at $37^{\circ} \mathrm{C}$, showed that the east-northeast (E-NE) and east-southeast (E-SE) regions of the catchment were the only in safe zones, whereas rest of regions was highly affected (Figure 5). Microbiological pathogens in the study area may due to a higher level of organic load which enhances microbial activity with high BOD (biochemical or biological oxygen demand) and TDS. Dissolved oxygen concentration provides useful information about water quality, regarding the stability of many organic and inorganic contaminants in groundwater.

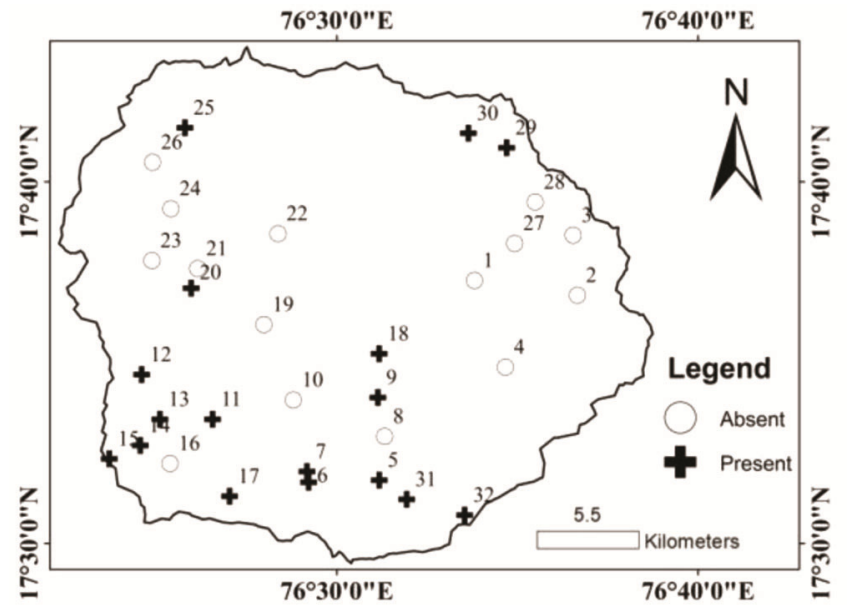

Figure 4. Sulphite reducing anaerobes in Amarja Reservoir Catchment.

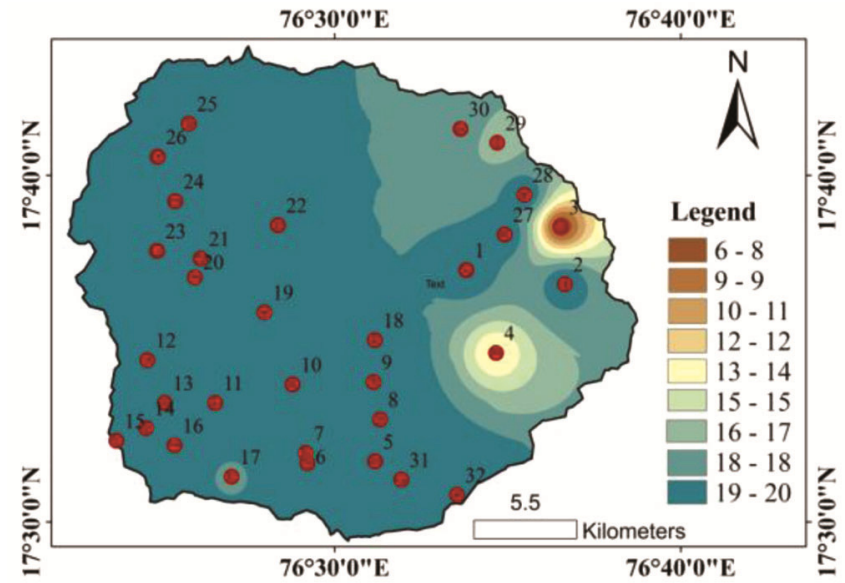

Figure 5. Aerobic plate count (APC) at $37^{\circ} \mathrm{C}$ in Amarja Reservoir Catchment. 
The conductivity values were in the range from $161 \mu \mathrm{s} / \mathrm{cm}$ to $1413 \mu \mathrm{s} / \mathrm{cm}$ (Figure 6) ${ }^{12}$. The electric conductivity was calculated using $\operatorname{TDS}^{12}$. Lower values were observed in the north-northeast, north-northwest and

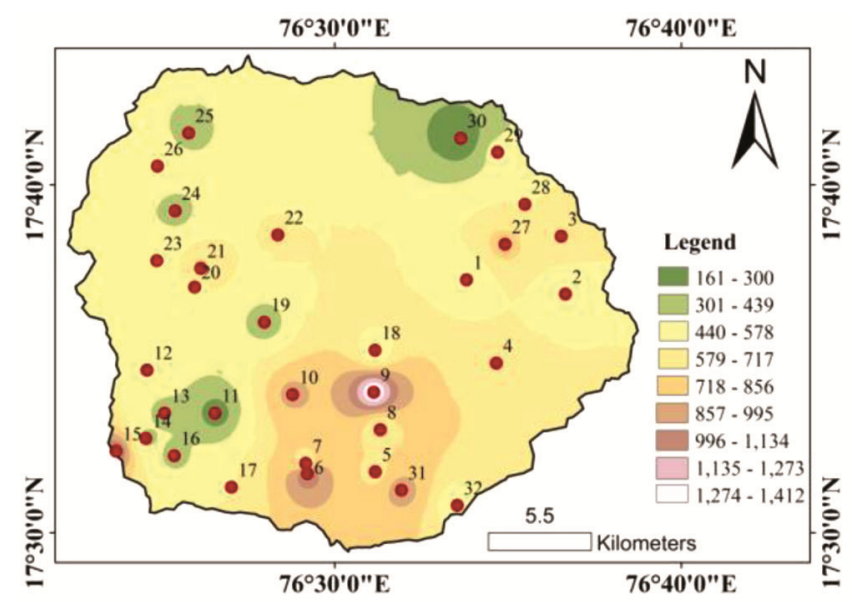

Figure 6. Electrical conductivity in Amarja Reservoir Catchment. some parts of the west-southeast region of the catchment, whereas in the southern and eastern regions of higher conductivity was recorded. Conductivity always increases as the concentration of ions increases ${ }^{8}$. TDS values in the analysed water sample were in the range 108-947 mg/l (Figure 7). The highest value of the TDS was recorded in the southern side of the catchment. The overall TDS of water in the study area showed an increasing tendency towards the lower part of the catchment, which may be due to the loading and accumulation of ionic compounds and contamination through surface water run-off. The $\mathrm{pH}$ value in the study area was in range 7.1-8.9. The SE and SW parts of the catchment showed higher $\mathrm{pH}$ (Figure 8). The lower $\mathrm{pH}$ of drinking water can cause gastrointestinal disorder, while higher values (alkaline nature) can affect functioning of the kidney. The turbidity of the catchment was recorded from 1.0 to 2.0 NTU (Figure 9). The highest turbidity value was recorded in the south-southeast part of the study area. Figure 10 represents the growth of bacteria at $37^{\circ} \mathrm{C}$ with respect to different location, indicating that almost all the villages have higher APC values.

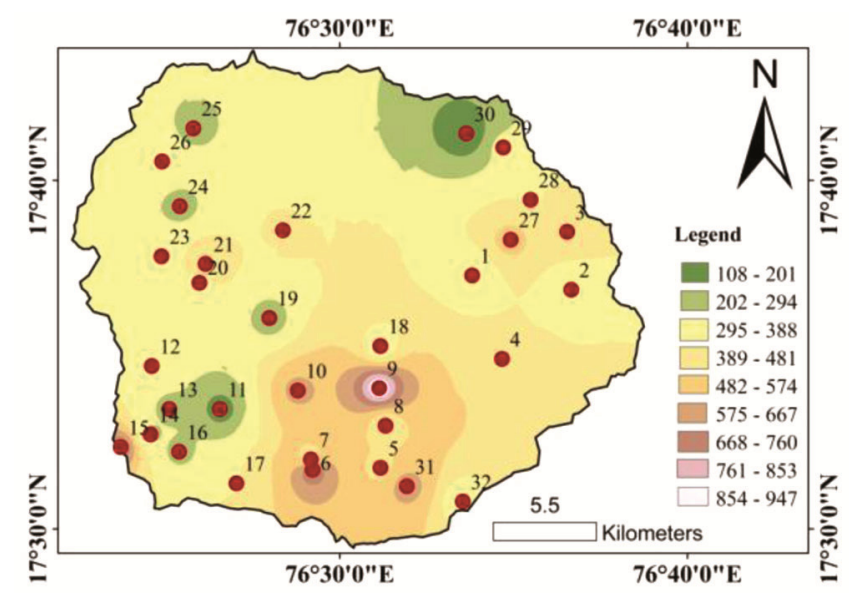

Figure 7. Total dissolved solids (TDS) in Amarja Reservoir Catchment.

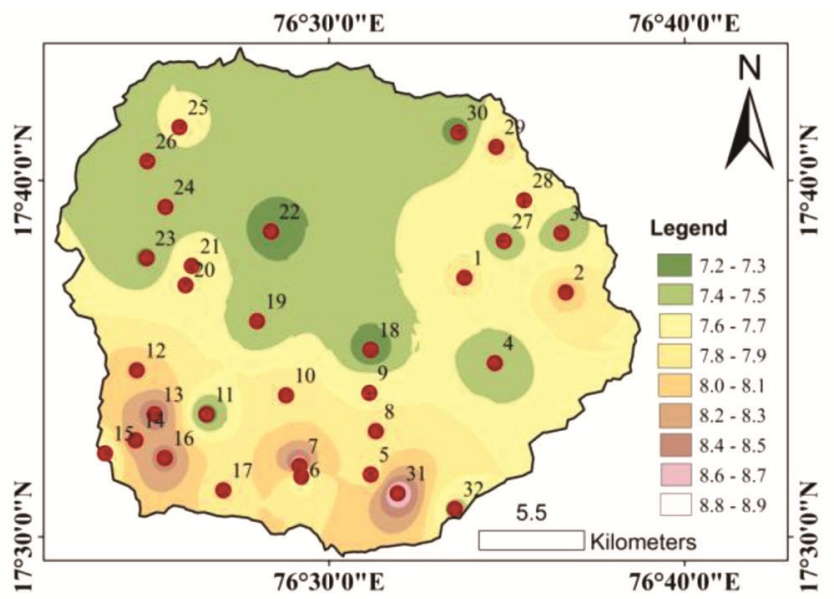

Figure 8. pH concentration in Amarja Reservoir Catchment.

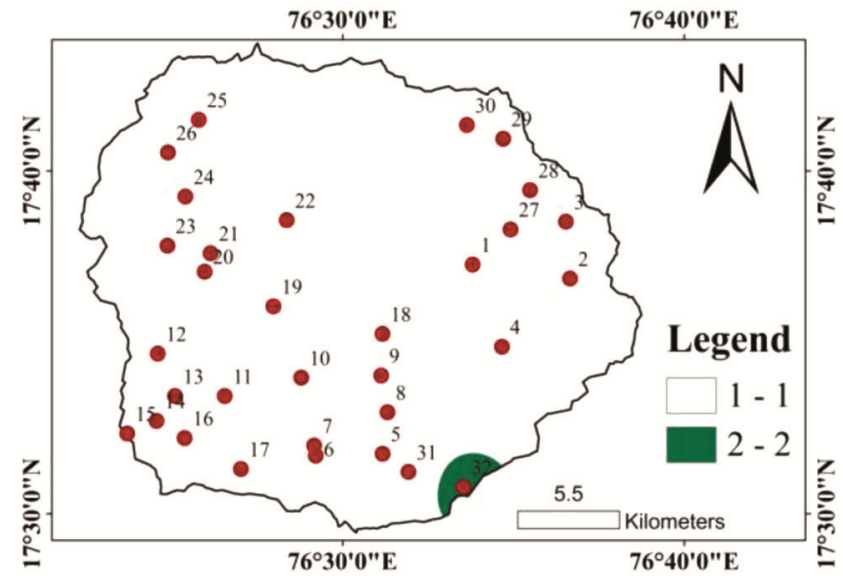

Figure 9. Turbidity in Amarja Reservoir Catchment.

25

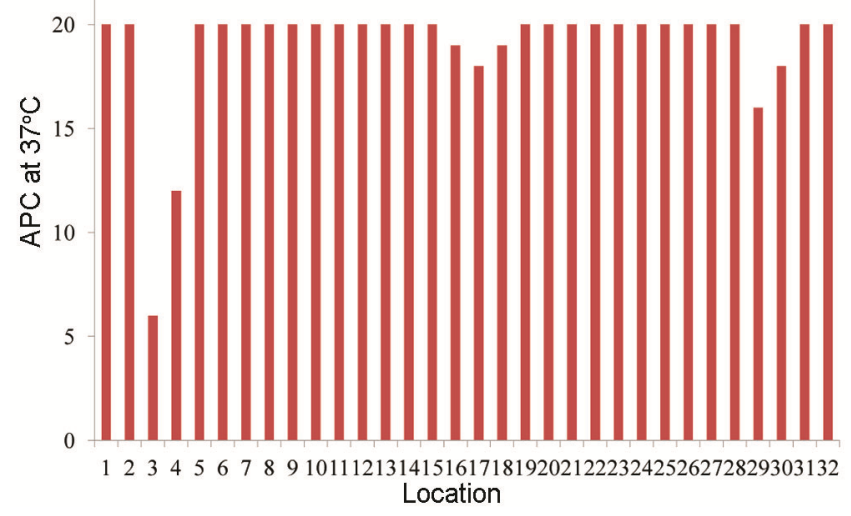

Figure 10. Growth of APC in different location. 
Table 2. Physical and microbiological parameters of water in Amarja reservoir catchment, Aland taluk, Karnataka

\begin{tabular}{|c|c|c|c|c|c|c|c|c|}
\hline Location & $\begin{array}{l}\text { Turbidity } \\
\text { (NTU) }\end{array}$ & $\mathrm{pH}$ & $\begin{array}{c}\text { Electrical } \\
\text { conductivity }(\mathrm{EC}) \\
(\mu \mathrm{S} / \mathrm{cm})\end{array}$ & $\begin{array}{c}\text { TDS } \\
(\mathrm{mg} / \mathrm{l})\end{array}$ & $\begin{array}{l}\text { Total coliform } \\
\text { and } E \text {. coli }\end{array}$ & $\begin{array}{c}\text { Pseudomonas } \\
\text { aeruginosa }\end{array}$ & $\begin{array}{l}\text { Sulphite-reducing } \\
\text { anaerobes }\end{array}$ & $\begin{array}{c}\text { Aerobic } \\
\text { plate count at } \\
37^{\circ} \mathrm{C}(\mathrm{cfu} / \mathrm{ml})\end{array}$ \\
\hline Telikuni & $<1$ & 7.82 & 444 & 298 & Present & Absent & Absent & $>20$ \\
\hline Kenisultan & $<1$ & 8.03 & 461 & 309 & Present & Present & Absent & $>20$ \\
\hline Jamga (R) & $<1$ & 7.42 & 673 & 451 & Absent & Absent & Absent & 6 \\
\hline Aland & $<1$ & 7.34 & 631 & 423 & Absent & Absent & Absent & 12 \\
\hline Jidga & $<1$ & 7.20 & 1229 & 824 & Absent & Absent & Present & $>20$ \\
\hline Jamga Khandala & $<1$ & 8.88 & 528 & 354 & Absent & Absent & Present & $>20$ \\
\hline Shakhapur & $<1$ & 7.76 & 570 & 382 & Present & Absent & Absent & $>20$ \\
\hline Jheerahalli & $<1$ & 7.71 & 1413 & 947 & Absent & Absent & Present & $>20$ \\
\hline Khanapur & $<1$ & 7.89 & 905 & 607 & Present & Absent & Absent & $>20$ \\
\hline Swaleshwar & $<1$ & 7.23 & 216 & 145 & Present & Absent & Present & $>20$ \\
\hline Sarasambha & $<1$ & 7.98 & 531 & 356 & Present & Present & Present & $>20$ \\
\hline Sakkarga & $<1$ & 8.27 & 402 & 270 & Present & Absent & Present & $>20$ \\
\hline Kamanalli & $<1$ & 7.50 & 1132 & 759 & Present & Present & Present & $>20$ \\
\hline Kinnihabas & $<1$ & 8.42 & 401 & 269 & Absent & Absent & Absent & 19 \\
\hline Mogha (B) & $<1$ & 7.81 & 574 & 385 & Present & Present & Present & 18 \\
\hline Hebli & $<1$ & 7.16 & 453 & 304 & Absent & Absent & Present & 19 \\
\hline Padsawli & $<1$ & 7.34 & 373 & 250 & Present & Absent & Absent & $>20$ \\
\hline Chincholi (K) & $<1$ & 7.71 & 510 & 342 & Present & Present & Present & $>20$ \\
\hline Chincholi(B) & $<1$ & 7.70 & 761 & 510 & Absent & Present & Absent & $>20$ \\
\hline Nirgudi & $<1$ & 7.24 & 601 & 403 & Present & Present & Absent & $>20$ \\
\hline Khairat & $<1$ & 7.31 & 492 & 330 & Absent & Absent & Absent & $>20$ \\
\hline Varnalwadi & $<1$ & 7.42 & 385 & 258 & Present & Present & Absent & $>20$ \\
\hline Aloor & $<1$ & 7.61 & 404 & 271 & Absent & Present & Present & $>20$ \\
\hline Bolegaon & $<1$ & 7.34 & 562 & 377 & Present & Present & Absent & $>20$ \\
\hline Chitali & $<1$ & 7.45 & 794 & 532 & Present & Present & Absent & $>20$ \\
\hline Bangerga & $<1$ & 7.75 & 571 & 383 & Present & Absent & Absent & $>20$ \\
\hline Bableshwar & $<1$ & 7.82 & 465 & 312 & Present & Absent & Present & 16 \\
\hline Korahalli & $<2$ & 7.49 & 458 & 307 & Absent & Present & Present & $>20$ \\
\hline
\end{tabular}

Table 3. Correlation between microbiological and physical parameters

\begin{tabular}{lccccc}
\hline Coefficient & TDS & Turbidity & $\mathrm{pH}$ & EC & APC at $37^{\circ} \mathrm{C}$ \\
\hline TDS & 1 & & & & \\
Turbidity & -0.09 & 1 & & & \\
pH & -0.004 & -0.09 & 1 & 1 & 1 \\
EC & 0.99 & -0.09 & -0.004 & -0.06 & \\
APC at $37^{\circ} \mathrm{C}$ & -0.06 & 0.03 & 0.13 & \\
\hline
\end{tabular}

A correlation matrix has been used to describe whether significant correlation exists between the appearance and growth of microbiological pathogens, and measured physical parameters. Pearson's correlation coefficient measures the degree to which two variables are linearly related. If the linear relationship between two variables is perfect with a positive slope, the Pearson's correlation coefficient becomes 1 (ref. 13). If the linear relationship between the two variables is negative, the Pearson's correlation coefficient becomes -1 (ref. 13). The coefficient having a value of ' 0 ' indicates that there is no relationship between the two variables ${ }^{13}$. Table 2 shows the analysed physical and microbiological parameters, whereas
Table 3 shows the correlation matrix obtained using these parameters.

The colony count at $37^{\circ} \mathrm{C}$ represents a positive relationship with respect to $\mathrm{pH}$ (Tables 3 and 4). The result is consistent with that of a study carried out by HabudaStanic et al. ${ }^{13}$. Figure 11 gives a clear representation of the growth of APC with an increasing $\mathrm{pH}$. The other values of correlation coefficients (Table 3 ) between APC and $\mathrm{EC}$, TDS, turbidity suggest that correlation does not exist among these parameters. The results also reveal that there is a strong relationship between TDS and EC. The scatter plots between the growth of APC at $37^{\circ} \mathrm{C}$ and TDS, EC, turbidity are shown in Figures 12-14 respectively. 
Table 4. Standard of correlation coefficient ${ }^{13}$

\begin{tabular}{lcccc}
\hline Coefficient & Strong relation & Moderate relation & Weak relation & None \\
\hline Positive correlation & 0.5 to 1.0 & 0.3 to 0.49 & 0.1 to 0.29 & 0 to 0.09 \\
Negative correlation & -1.0 to -0.5 & -0.49 to -0.3 & -0.29 to -0.1 & -0.09 to 0 \\
\hline
\end{tabular}

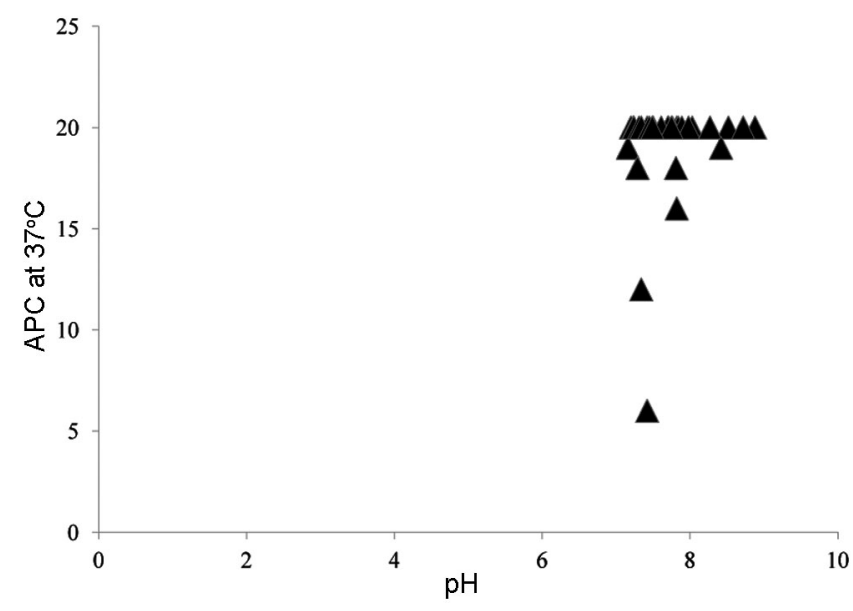

Figure 11. Relationship between total plate count and $\mathrm{pH}$.

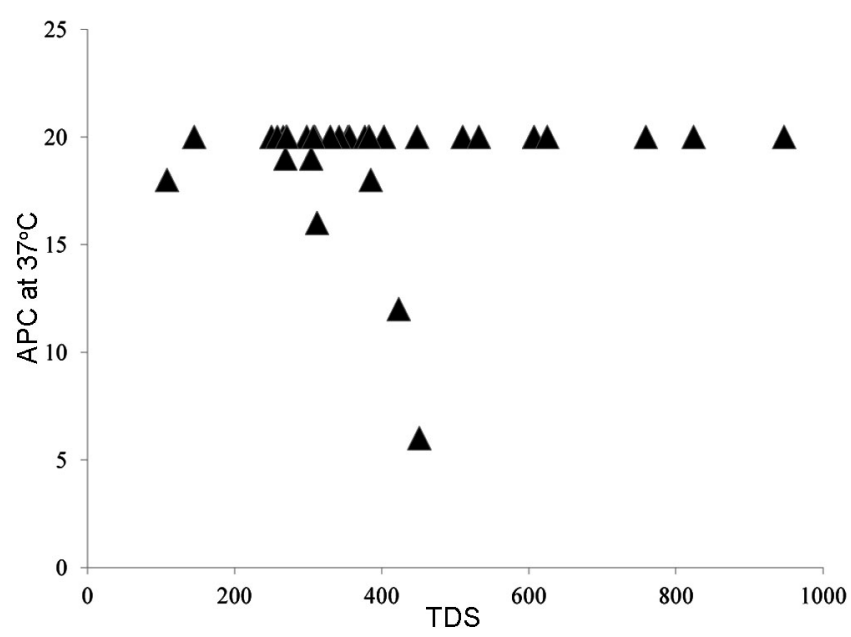

Figure 12. Relationship between total plate count and TDS.

The confirmation of $E$. coli indicates that the contamination of media exist near the source of these pathogens ${ }^{14}$. One of the most dangerous species of $E$. coli, $E$. coli O157:H7 (ref. 15) several disease to outbreaks ${ }^{1}$. Moreover, it is also responsible for kidney failure, gastroenteric infection, pneumonia, urinary tract infection $^{14}$ and respiratory illnesses. The most common symptoms of these diseases are vomiting, nausea, diarrhoea, fever and stomach cramps.

$P$. aeruginosa is considered as an expedient pathogen. Several diseases occur due to $P$. aeruginosa, like urinary infection, dermatitis, soft tissue infection, bacteraemia, respiratory system infection, joint and bone infection,

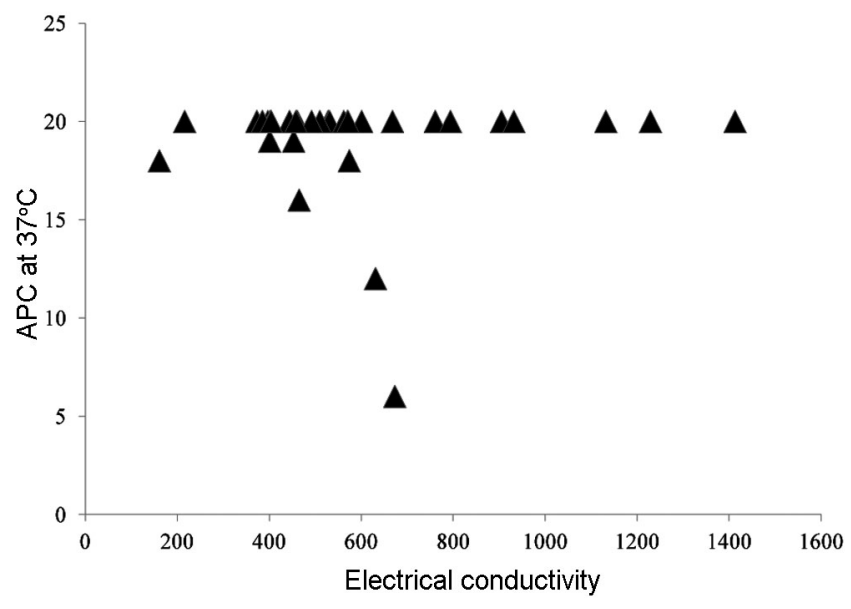

Figure 13. Relationship between total plate count and electrical conductivity.

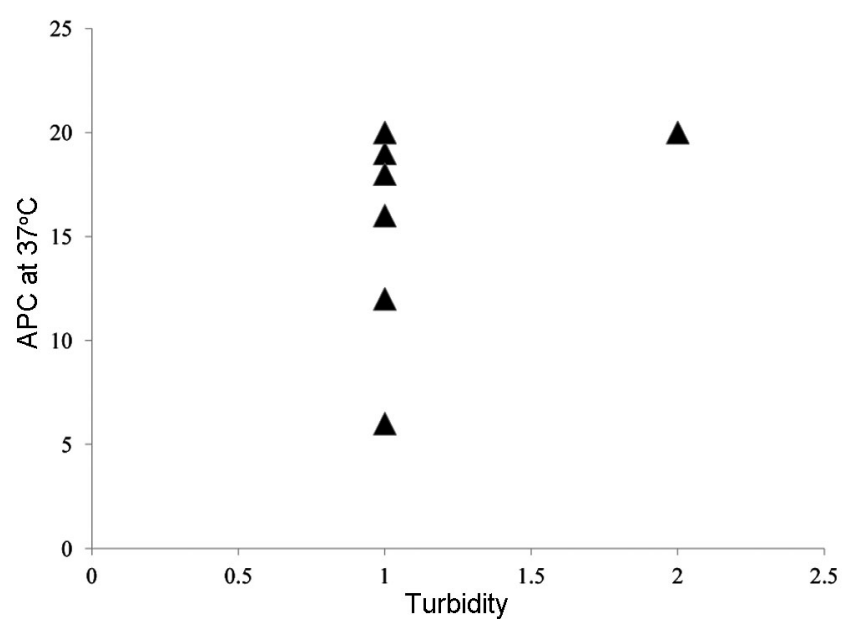

Figure 14. Relationship between total plate count and turbidity.

gastrointestinal infection and a diverseness of systemic infections ${ }^{13,16,17}$. In addition, most of the outbreaks have been recorded in swimming pools and water slides due to exposure to $P$. aueroginosa pathogens. Skin exposure in hot tubs and lung exposure from inhaling aerosols are the most common infections occur due to water infected by $P$. aeruginosa ${ }^{18}$. To reduce the infections and colonization caused by $P$. aeruginosa, it is recommended to use filters on water taps.

Clostridium perfringens, Clostridium botulinum and Clostridium tetani are the most common types of sulphitereducing anaerobes. $C$. perfringens causes food poisoning, fasciitis and gas gangrene; C. botulinum causes botulism, 
RESEARCH COMMUNICATIONS

Table 5. Types of water exposure and related diseases ${ }^{20}$

\begin{tabular}{|c|c|c|c|c|}
\hline Classification & Description & Type of water exposure & Sub-class & Examples \\
\hline $\begin{array}{l}\text { Waterborne microbial } \\
\text { diseases }\end{array}$ & $\begin{array}{l}\text { Diseases due to consumption } \\
\text { of water contaminated with } \\
\text { bacteria; most of them due } \\
\text { to animal and human faecal } \\
\text { contamination of water. }\end{array}$ & Drinking water & $\begin{array}{l}\text { Treated or untreated water; } \\
\text { public or private supply. }\end{array}$ & $\begin{array}{l}\text { Viral, typhoid, cholera, } \\
\text { gastroenteritis, e.g. due to } \\
\text { the effect of Norovirus }\end{array}$ \\
\hline $\begin{array}{l}\text { Waterborne chemical } \\
\text { diseases }\end{array}$ & $\begin{array}{l}\text { Disease due to ingestion of } \\
\text { toxic material in the water. }\end{array}$ & Drinking water & $\begin{array}{l}\text { Treated or untreated water; } \\
\text { public or private supply. }\end{array}$ & Arsenicosis \\
\hline Water contact diseases & $\begin{array}{l}\text { Caused by skin contact with } \\
\text { pathogen-infested water or } \\
\text { with chemical-contaminated } \\
\text { water. }\end{array}$ & Recreational water & $\begin{array}{l}\text { Freshwater sources; } \\
\text { marine waters. }\end{array}$ & $\begin{array}{l}\text { Schistosomiasis (bilharzia); } \\
\text { cyanobacteria. }\end{array}$ \\
\hline Water hygiene diseases & $\begin{array}{l}\text { Diseases whose incidence, } \\
\text { prevalence or severity can } \\
\text { be reduced using safe } \\
\text { (clean) water to improve } \\
\text { personal and domestic } \\
\text { hygiene. }\end{array}$ & $\begin{array}{l}\text { Any water used for } \\
\text { washing/personal } \\
\text { hygiene. }\end{array}$ & $\begin{array}{l}\text { Diseases related to } \\
\text { variations in } \\
\text { water quality; } \\
\text { diseases related } \\
\text { to water shortage. }\end{array}$ & $\begin{array}{l}\text { Scabies, shigellosis; } \\
\text { trachoma. }\end{array}$ \\
\hline Water vector habitat diseases & $\begin{array}{l}\text { Diseases where the vector } \\
\text { lives all or part of its life } \\
\text { in or adjacent to a water } \\
\text { habitat. }\end{array}$ & $\begin{array}{l}\text { Untreated freshwater } \\
\text { sources. }\end{array}$ & $\begin{array}{l}\text { Rivers, streams; } \\
\text { small collections of } \\
\text { stagnant water, } \\
\text { e.g. water butts. }\end{array}$ & $\begin{array}{l}\text { Malaria, filiariasis, } \\
\text { onchocerciasis } \\
\text { (aquatic flies); } \\
\text { schistosomiasis (snails); } \\
\text { trypanosomiasis } \\
\text { (tsetse flies). }\end{array}$ \\
\hline Water aerosol diseases & $\begin{array}{l}\text { Diseases due to respiratory } \\
\text { transmission, where a water } \\
\text { aerosol containing suspended } \\
\text { pathogens enters the airway. }\end{array}$ & $\begin{array}{l}\text { Drinking or raw } \\
\text { water sources. }\end{array}$ & $\begin{array}{l}\text { Water used in industrial/ } \\
\text { residential buildings } \\
\text { Raw water sources. }\end{array}$ & $\begin{array}{l}\text { Legionellosis (Legionnaires' } \\
\text { disease; humidifier fever); } \\
\text { Norwalk-like viral } \\
\text { gastroenteritis. }\end{array}$ \\
\hline Excreta disposal diseases & $\begin{array}{l}\text { Diseases related to unsanitary } \\
\text { disposal of human waste } \\
\text { (faeces and urine). }\end{array}$ & $\begin{array}{l}\text { Drinking water and } \\
\text { untreated water } \\
\text { sources. }\end{array}$ & $\begin{array}{l}\text { Diseases related to human/ } \\
\text { animal waste in drinking } \\
\text { water; disease related to } \\
\text { direct/indirect contact } \\
\text { with faeces/urine. }\end{array}$ & $\begin{array}{l}\text { Ascariasis; faecal-oral } \\
\text { infections, e.g. shigellosis; } \\
\text { schistosomiasis, trachoma. }\end{array}$ \\
\hline
\end{tabular}

while $C$. tetani causes tetanus infections, Clostridium sordellii is another important species of sulphite-reducing anaerobes which is responsible for fatal infections.

APC is a valuable parameter for evaluating water and food quality. A higher count of colonies can also be an indication of poor sanitation. Therefore, it is important to assess the water and food for specific pathogens before ruling on their quality. APC are the poor indicators of safety in most cases. They do not make any direct correlation to the presence of pathogens or toxins. A low colony count does not indicate that the ingredient is free from bacteria. Moreover, some pathogens show excessively high colony count which can result in a potential health hazard $^{19}$. Table 5 lists some water exposure diseases that have been classified by Stanwell-Smith ${ }^{20}$.

In this study, microbial analysis was conducted at the Amarja reservoir catchment. Most of the analysed water samples were found to be contaminated. The lower part of the catchment was alkaline in nature, whereas the southeastern part showed higher TDS concentration. The total coliform and $E$. coli and sulphite-reducing anaerobes clearly indicated increasing tendency towards the downstream parts of the catchment. The northern and southern parts of the catchment were highly affected by Pseudomonas. Many villages of the study area have been affected with bacterial growth at $37^{\circ} \mathrm{C}$ and this may due to the slightly alkaline nature of drinking water $(\mathrm{pH} 6.5$ 7.5). The study revealed that the catchment has been highly affected with microbial pathogens, giving rise to an alarming situation from the public health point of view. GIS-based spatial distribution maps are useful in the better understanding of vulnerable zones of the catchment for adopting a better management strategy, as done in this study. The results suggest that groundwater in the lower part of the catchment needs appropriate treatments before use for domestic consumption.

1. Rajendra, S., Rubin, D. and Abhishek, M., Microbiological quality of potable water in Dehradun city. Int. Res. J. Pharma., 2012, 3(6), 130-137.

2. Palamuleni, L. and Akoth, M., Physico-chemical and microbial analysis of selected borehole water in Mahikeng, South Africa. Int. J. Environ. Res. Public Health, 2015, 12(8), 8619-8630. 
3. Macy, J. T. and Quick, R. E., Transmission and prevention of water-diseases. In Encyclopedia of Life Support System, Eolss Publishers Co Ltd, Oxford, UK, 2009, ISBN: 978-1-84826$182-2$

4. Mena, K. D. and Gerba, C. P., Risk assessment of Pseudomonas bacteria in water. Rev. Environ. Contam. Toxicol., 2009, 201, $71-115$.

5. LeChevallier, M. W., Conditions favouring coliform and HPC bacterial growth in drinking water and on water contact surfaces. In Heterotrophic Plate Counts and Drinking-Water Safety, IWA Publishing, London, UK, 2003; http://www.who.int/water sanitation health/dwq/HPC10.pdf

6. Smith, D. P., Cason, J. A., Fletcher, D. L. and Hannah, J. F., Evaluation of carcass scraping to enumerate bacteria on prechill broiler carcasses. Polut. Sci., 2007, 86(7), 1436-1439.

7. Barrel, R. A. E., Hunter, P. R. and Nichols, G., Microbiological standards for water and their relationship to health risk. Commun. Dis. Public Health, 2000, 3(1), 8-13.

8. Majagi, S., Vijaykumar, K., Rajshekhar, M. and Vasanthkumar, B., Chemistry of groundwater in Gulbarga district, Karnataka, India. Environ. Monit. Assess., 2008, 136, 347-354.

9. Groundwater Information Booklet, Gulbarga District, Karnataka South-Western Region, Bangalore, 2012; http://cgwb.gov.in/ District Profile/karnataka/2012/Gulbarga-2012.pdf

10. Chaidez, C., Soto, M., Martinez, C. and Keswick, B., Drinking water microbiological survey of the Northwestern State of Sinaloa, Mexico. J. Water Health, 2008, 6(1), 125-129.

11. Collins, C. H., Lyne, P. M. and Grange, J. M., Microbiological Methods, Oxford University Press Inc, New York, USA, 2004

12. Atekwanaa, E. A., Atekwanaa, E. A., Roweb, R. S., Werkema, D. D. and Legalld, F. D., The relationship of total dissolved solids measurements to bulk electrical conductivity in an aquifer contaminated with hydrocarbon. J. Appl. Geophys., 2004, 56(4), 281294

13. Habuda-Stanic, M., Santo, V, Sikora, M. and Benkotic, S., Microbiological quality of drinking water in public and municipal drinking water supply systems in Osijek-Baranja County, Croatia. Croat. J. Food Sci. Technol., 2013, 5(2), 61-69.

14. Amenu, D., Bacteriological and physicochemical quality of well water sources. Res. J. Chem. Environ. Sci., 2014, 2(5), 13-27.

15. Hunter, P. R., Colford, J. M., LeChevallier, M. W., Binder, S. and Berger, P. S., Waterborne diseases. Emerg. Infect. Dis., 2001, 7(3), 544-545.

16. Al Moosa, M. E., Khan, M. A., Alalami, U. and Husaain, A., Microbiological quality of drinking water from water dispenser machines. Int. J. Environ. Sci. Develop., 2015, 6(9), 710-713.

17. Ashbolt, J. N., Microbial contamination of drinking water and disease outcomes in developing regions. Toxicology, 2004, 198, 229-238.

18. Shakya, P., Joshi, T. P., Joshi, D. R. and Bhatta, D. R., Evaluation of physico-chemical and microbiological parameters of drinking water supplied from distribution systems of Kathmandu Municipality. Nepal J. Sci. Technol., 2012, 13(2), 179-184.

19. Medha, A. and Hysko, M., Assessment of water quality of Buna River using microbiological analysis. Albanian J. Agric. Sci., 2014, 13, 113-116.

20. Stanwell-Smith, R., Classification of water-related disease. In Encyclopedia of Life Support System, Eolss Publishers Co. Ltd, Oxford, UK, 2009; http://www.eolss.net/sample-chapters/c03/e220a-01-01.pdf

Received 22 May 2018; revised accepted 8 May 2019

\section{Production of novel bio-flocculants from Klebsiella variicola BF1 using cassava starch wastewater and its application}

\author{
Ngoc Tuan Nguyen ${ }^{1, *}$, Thi Ha My Phan ${ }^{2}$, \\ Tuyet Nhung Tran ${ }^{3}$, Bharath Kumar \\ Velmurugan ${ }^{1}$ and Rudolf Kiefer ${ }^{3}$ \\ ${ }^{1}$ Toxicology and Biomedicine Research Group, Faculty of Applied \\ Sciences, Ton Duc Thang University, Ho Chi Minh City, Vietnam \\ ${ }^{2}$ Institute of Microbiology and Immunology, National Yang-Ming \\ University, Taipei, Taiwan \\ ${ }^{3}$ Faculty of Applied Sciences, Ton Duc Thang University, \\ Ho Chi Minh City, Vietnam
}

In this study, Klebsiella variicola BF1 that uses cassava starch wastewater to produce flocculants was identified using 16S rDNA gene sequencing. The pure flocculants of strain BF1 could be easily extracted by ethanol precipitation with a high yield of $7.5 \mathrm{~g} / \mathrm{l}$. It was mainly composed of $83.1 \%$ carbohydrates and $10.6 \%$ proteins. The flocculating activity revealed $97.6 \pm$ $0.6 \%$ for kaolin suspension at $12.8 \mathrm{mg} / \mathrm{l}$ extracted flocculants from strain $\mathrm{BF} 1$ and $2.5 \mathrm{~g} / \mathrm{l} \mathrm{CaCl}_{2}$. Interestingly, the flocculating activity was $78 \%$ without the addition of metal ions. Furthermore, flocculants of strain BF1 can be effectively applied in the treatment of cassava starch wastewater and municipal wastewater.

Keywords: Cassava starch, exopolysaccharide, flocculants, Klebsiella variicola, wastewater treatment.

FLOCCULANTS are widely used in industrial processes, including wastewater treatment, textiles, detergents, adhesives and oil recovery ${ }^{1,2}$. Flocculants consist of two main classes: (1) chemical flocculants such as polyacrylamide, polyelectrolytes, polyethyleneimine, polyaluminium chloride and aluminium sulphate, and (2) natural flocculants such as cellulose, microbial flocculants, gelatin, chitosan, gum and mucilage, sodium alginate and tannin ${ }^{1,2}$. The chemical flocculants have been widely used in various applications due to their effectiveness and low cost. However, chemical flocculants can negatively affect ecosystems. Therefore, it is important to replace chemical flocculants by biodegradable flocculants.

Microbial flocculants have attracted research interest ${ }^{3-14}$. Bacteria, fungi and algae are known to be responsible for the production of flocculants ${ }^{4-11,13,14}$. The large-scale production and recovery of bio-flocculants has been stu$\operatorname{died}^{4-11,13,14}$. Therefore, they are widely applied in many industrial sectors. For the aim of commercialization, a considerable effort has gone into reducing the production cost through using some wastes rich in organic matter,

*For correspondence. (e-mail: nguyenngoctuan@tdtu.edu.vn) 